\title{
Determination of source seismic parameters of micro-earthquakes with epicenter in the south of Minas Gerais State - Brazil
}

\author{
Lucas Vieira Barros $^{1}$, Juraci Carvalho ${ }^{1}$, Vinicius Martins Ferreira ${ }^{1}$, Diogo Farrapo de Albuquerque ${ }^{1}$, Mônica G. Von \\ Huelsen ${ }^{1}$, Daniel F. de Caixeta ${ }^{1}$ and Darlan Portela Fontenele ${ }^{1}$. \\ 1 Observatório Sismológico - UnB, Brasília - DF, Brasil - lucas@unb.br
}

Copyright 2014, SBGf - Sociedade Brasileira de Geofísica

Este texto foi preparado para a apresentação no VI Simpósio Brasileiro de Geofísica, Porto Alegre, 14 a 16 de outubro de 2014. Seu conteúdo foi revisado pelo Comitê Técnico do VI SimBGf, mas não necessariamente representa a opinião da SBGf ou de seus associados. É proibida a reprodução total ou parcial deste material para propósitos comerciais sem prévia autorização da SBGt.

\section{Abstract}

In this work we present the seismicity of Funil reservoir power plant, located close to the three potential sources of triggered seismicity, comprising the events recorded by a seismic network composed by six stations and running during five months. Briefly we discuss the seismicity without a conclusion on its nature, triggered or not triggered. The conclusion will require more studies. The events (natural and artificial) hypocentral locations were made with hypocenter program in SEISAN data analysis package. The seismic sources parameters were determined by $\mathrm{P}$-wave polarities, composite focal mechanism, and by moment tensor waveform inversion method. The results from both methods where compared and show some disagreement which could be related to the fact that was used only a single event inverted in the frequencyband of $1 \mathrm{~Hz}$ to $2 \mathrm{~Hz}$. Despite this disagreement, the stress regime obtained from both methods is more less the same, inverse faulting with compression axis roughly E-W direction, concordant with theoretical models, developed by different actors.

\section{Introduction}

Funil reservoir is located in the south of Minas Gerais State, southeastern of Brazil, in the middle of São Francisco Craton. Nearby the reservoir there are three potential sources of triggered seismicity: the lake itself, mining activities and water table variation due to large scale water pumping. On August 14th, 2011, a local seismic station installed near to the reservoir detected one earthquake of magnitude 3.2 on the Richter scale. This event was felt more strongly in the town of ljaci, located on the left margin of the Funil reservoir. On October 5, November 13 and November 23 of 2011, ljaci residences were again shaken by new seismic occurrences. As a result, in December of 2011, the Seismological Observatory of the University of Brasilia, in a partnership with the FUNIL Consortium, deployed a local seismographic network with six stations to better study this seismicity. Before that, a local seismic station (FUN1) was installed close to the reservoir in December of 2010. Together they composed a local network with seven stations.

Some quarries in the region make systematic chemical detonations, without precise scheduling information, and when this is accomplished, it is done inaccurately.
This hampers the discrimination of tectonic events from artificial events, considering the similarity between the waveforms of certain bursts with those generated by natural events in the same area.

So, it is difficult to analyze the data because some explosion records are much like the records of natural earthquakes and therefore discrimination is very difficult and time consuming.

The network operated from December 28 of 2011 to May 23 of 2012, and during these five months it were detected more than 1000 seismic events (natural and artificial), from which 500 had their hypocenter determined, but only about 70 with good accuracy (Table 1). The events were located very close to the lake and in the area of four quarries in the region (Fig. 1 ). In these areas no previous natural seismicity had been detected before.

In order to get focal mechanism solution, it was made a selection of ten events with, magnitudes ranging from 0.3 to 1.6 , the selection criteria followed the hypocentral location accuracy, and from this set, five 5 events with magnitudes varying from 1.2 to 1.6 were used to made waveform inversion using ISOLA package (Table 2).

Therefore, the goal of this work is to present the results of source seismic parameters of the best events of the Funil reservoir seismic sequence using two methods; composite focal mechanism and waveform inversion, and see if their results are in agreement, as well as the to discuss how to discriminate tectonic events from some artificial events occurred in this area.

\section{Data and analysis}

The Funil reservoir seismicity began in December 2010, as soon as the FUN1 station was installed. However, only in August 14, 2011 occurred the biggest event (magnitude $3.2 \mathrm{mR}$ and MMI IV-V). This event was located close to the ljaci town, in the left margin of the lake, event 1 of Fig. 1 (blue stars). The occurrence of such event and three others with similar magnitudes, in October and November of the same year, all felt by ljaci inhabitants, led to the installations of six seismograph stations, four broad-band $(30 \mathrm{~s}-50 \mathrm{~Hz})$ and two shortperiod $(1 \mathrm{~Hz}-100 \mathrm{~Hz})$. The instruments recorded data continuously at a sample rate of 100 sps. The FUN1 station detected most of the events, as the network was installed only on December 28, 2011 and operated up to May 25, of 2012, when it was disassembled. However, the station FUN1 remains in operation up to now. 
We analyzed data acquired between August 14, 2011, the day of the ljaci main event, and May 25, 2012, when the network was dismounted, leaving only the station FUN1. During this period, 1020 events were detected of which approximately 500 were located (241 artificial events - explosions and 276 natural events) (Table 1). The majority of the events were located with data of a single 3C station, especially FUN1 station (Table 1). The main quarries in the region are shown in Figure 1: Camargo Correia North (CC2), Camargo Correia South (CC1), Alvarenga (AV) and Mina Santa Helena (SN).

\section{Hypocentral location}

The 76 events shown in Fig. 1: 48 explosions (yellow circles); 24 (naturals events (red circles) and 4 main events (blue stars) were located using hypocenter program (Lienert, 1994) running in SEISAN (Havskov and Ottomöller, 2008) software. The velocity model used was a half space with P-wave velocity of $6.0 \mathrm{~km} / \mathrm{s}$ and a $\mathrm{Vp} / \mathrm{Vs}$ ratio of 1.72 , determined by Wadati diagram (Barros, et. al, 2013). FUN3 station, the closest to the source, was present in almost all events location. The minimum distance average is about $3 \mathrm{~km}$, except three or four out of the main group area shown in the Fig. 2.

Table 1: List of events located by number of stations.

\begin{tabular}{cccc}
\hline $\begin{array}{c}\text { Events located by } \\
\text { number of stations }\end{array}$ & Explosions & Natural & Total \\
\hline 1 or more stations & 241 & 276 & 517 \\
2 or more stations & 144 & 87 & 231 \\
3 or more stations & 106 & 50 & 156 \\
4 or more stations & 77 & 27 & 104 \\
5 and 6 stations & 28 & 7 & 35 \\
\hline
\end{tabular}

All the events were located using data of four or more stations, up to six and the maximum, minimum and average of azimuthal gap coverage were, respectively: $100^{\circ}, 250^{\circ}$ and $180^{\circ}$ (for 24 natural events) and $100^{\circ}$, $234^{\circ}$ and $168^{\circ}$ (for 48 artificial events). However, the events $1,2,3$ and 4 were located using only data of FUN1 station.

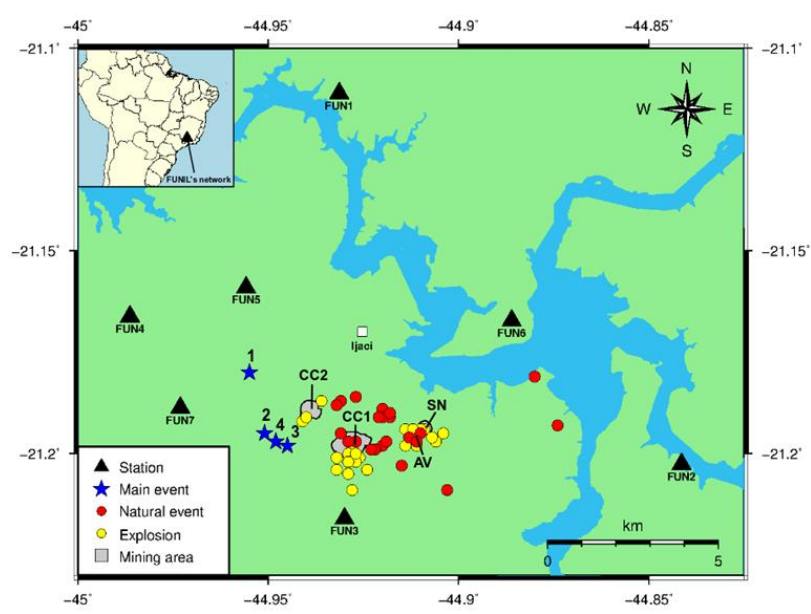

Fig. 1: - Distribution of epicenters of the natural (red circles) and artificial (yellow circles) events detected by four or more stations, up to six. The four blue stars denote the epicenters of major natural ljaci events. Event 1, August 14th, event2, October 5, event 3 and 4, November 13 and 23 of 2012, respectively (all of them were located with only FUN1 station).

Table 2: Events used in the composite focal mechanism solution and for waveform inversion.

\begin{tabular}{|c|c|c|c|c|c|}
\hline Event Number & Date (yyyy/mm/dd) & Origin Time (UTC) & Coordinate (DDMM) & Depth/Magnitude* & RMS \\
\hline 1 & $2012 / 02 / 24$ & $20: 09: 10.23$ & $-21-10.81-44-52.88$ & $0.4 / 1.4$ & 0.01 \\
\hline 2 & $2012 / 04 / 21$ & 03:22:42.39 & $-21-11.70-44-55.88$ & $0.6 / 1.0$ & 0.01 \\
\hline 3 & $2012 / 04 / 22$ & $15: 15: 54.36$ & $-21-11.46-44-55.11$ & $0.5 / 1.2$ & 0.00 \\
\hline 4 & $2012 / 04 / 22$ & $15: 52: 10.45$ & $-21-11.85-44-55.14$ & $0.3 / 1.4$ & 0.01 \\
\hline 5 & 2012/03/01 & 20:02:26.69 & $-21-11.37-44-55.18$ & $0.1 / 1.3$ & 0.05 \\
\hline 6 & $2012 / 03 / 06$ & $05: 45: 16.97$ & $-21-11.84-44-55.15$ & $0.0 / 1.6$ & 0.02 \\
\hline 7 & $2012 / 03 / 06$ & $05: 48: 27.10$ & $-21-11.87-44-55.18$ & $0.0 / 0.3$ & 0.02 \\
\hline 8 & $2012 / 05 / 18$ & 02:46:21.08 & $-21-12.54-44-54.22$ & $0.6 / 1.1$ & 0.01 \\
\hline 9 & $2012 / 05 / 18$ & 22:00:14.51 & $-21-11.95-44-55.40$ & $0.3 / 0.9$ & 0.01 \\
\hline 10 & $2012 / 05 / 19$ & $21: 40: 42.26$ & $-21-11.57-44-52.47$ & $0.0 / 1.0$ & 0.02 \\
\hline
\end{tabular}

*Depth is in $\mathrm{km}$ and magnitude is coda duration.

The four main events have different locations (Fig. 1), especially event 1 in relation to the others (2, 3 and 4$)$, more or less $2 \mathrm{~km}$ away, the differences are not related to miss location, as can be seen in Fig.2, which shows the vertical component of the ground movement of the four events in FUN1 station, in order of occurrence. Between events 1 and the others there is a difference of about 200 milliseconds in S-arrival times. This effectively justifies the four events location in Fig. 1. Moreover, events 3 and 4, for which there is good correlation between the P-waveforms (Fig.3) (this ensure the same azimuth for both events) and good Sphase correlation (this ensure the same S-P times for both events) (Fig 3). 


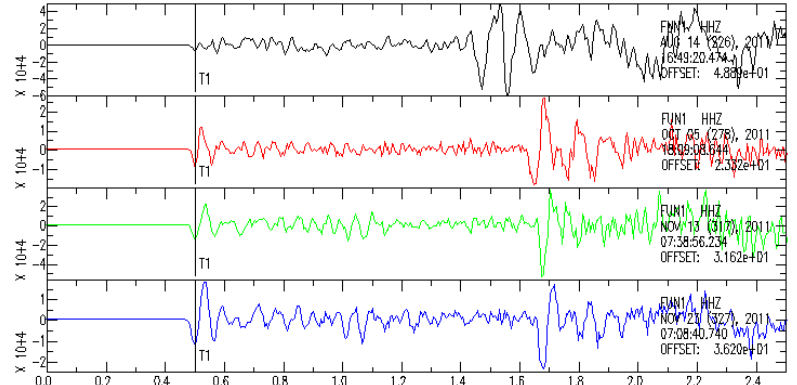

Fig 2: - Formas de ondas (componente vertical - Z) de todos os eventos principais (mainshock) registrados em 2011. Observa-se que o primeiro evento (14/08 - 16:49 (UTC)) distingue-se das demais formas de ondas pela chegada da onda S adiantada cerca de $200 \mathrm{~ms}$.

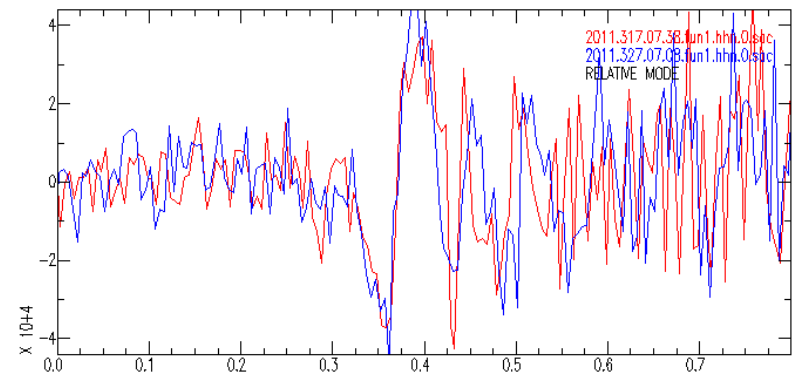

Fig. 3: - Correlação da fase S na estação FUN1, para os eventos do dia 13 e 23 de novembro de 2011, componentes $\mathrm{N}-\mathrm{S}$, sem filtragem.

\section{Focal Mechanism determination}

Focmec (Snoke, J.A, 2003) was used for the composite focal mechanism determination, using a set of ten events from the best located events (Table 2) and Fig. $4)$.

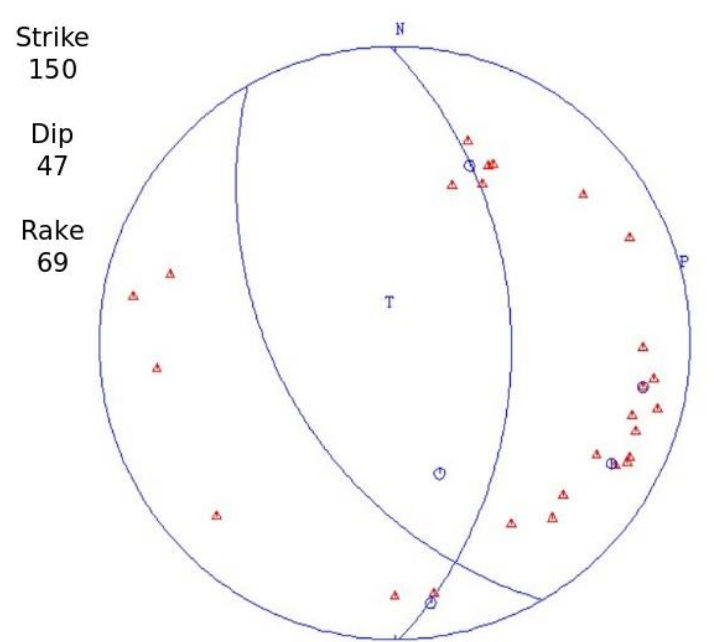

Fig. 4: - Composite Focal mechanism for Funil seismic sequence, using the first $\mathrm{P}$-wave polarities of a set of ten events. Circles are compression and triangles are distention.

\section{Waveform inversion}

The inversion was performed using the ISOLA code (Zahradnik et al, 2005; Sokos and Zahradinik 2008), MATLAB and an iterative method, similar to Kikuchi
Kanamori (1991). Green's functions were calculated using a half space of $6.0 \mathrm{~km} / \mathrm{s}$ and $\mathrm{a} \mathrm{Vp} / \mathrm{Vs}=1.72$, and the method of discrete wave number of Bouchon (1981).

As the location residuals of the events were in the order of about $10 \mathrm{~ms}$, i.e., the locations were accurate; the calculations of Green functions were made with the position of the source fixed and varying the vertical (depth) position. Starting at a depth of $0.5 \mathrm{~km}$ going up to $3.0 \mathrm{~km}$, in steps of $0.5 \mathrm{~km}$.

\section{Results}

The Fig. 2 shows the location of all events, naturals (24 - red circles), artificias (48 - yellow circles) and the main events (four blue stars). The yellow circles are more or less inside the mining areas (CC1, CC2, AV and $\mathrm{SN}$ ) and some natural events are very close or inside the mining area too.

A probable NNW-SSE fault is the solution for the composite focal mechanism determination (Fig. 4) with the following parameters: Strike $=150^{\circ}$, Dip $=47^{\circ}$ and Rake $=69^{\circ}$. The Fig. 5 shows the corresponding focal mechanism from the ISOLA waveform inversion of a single event (event 1 of Table 2), in the band of $1 \mathrm{~Hz}$ to $2 \mathrm{~Hz}$, using waveforms of four stations (FUN3, FUN4, FUN5 and FUN6) and, additionally in the Figure is plotted the polarities for each station. As we can see, there are no inconsistence between these polarities and the focal mechanism solution (Fig. 5).

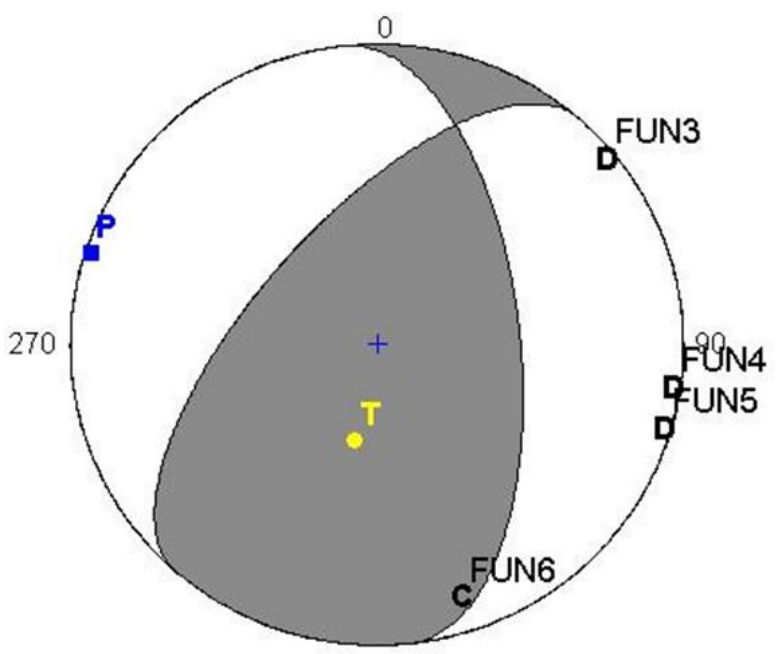

180

Fig.5: - Focal mechanism solution for the event of February 22 of 2012, at 20:09:10.23, using waveform inversion with ISOLA. Additionally the stations polarities were plotted and no inconsistency is present.

The Figure 6 shows all source parameters obtained by the waveforms inversion of event February 22, 2012, at 20:09:10.23. For the ISOLA was used the following parameters: coda wave magnitude $=1.4 \mathrm{mD}$, depth $=$ $0.4 \mathrm{~km}$ and epicenter equal to $21.180 \mathrm{~S}$ and $44.881 \mathrm{~W}$. As a result, was obtained magnitude $1.1 \mathrm{Mw}$ and centroid origin time equal to hypocenter origin time plus 150 mile seconds. The centroid moment tensor was located in the epicenter with a depth of $0.6 \mathrm{~km}$. Due to the good accuracy in the epicenter location the 
solutions were tried only with vertical variation. The inversion obtained $98.4 \%$ of DC (double couple). The correlation between synthetics and observed is better in
FUN6 station, as expected, because this is the closest station (see Fig.7). Table 3 summarizes the fault parameters gotten by both methods.

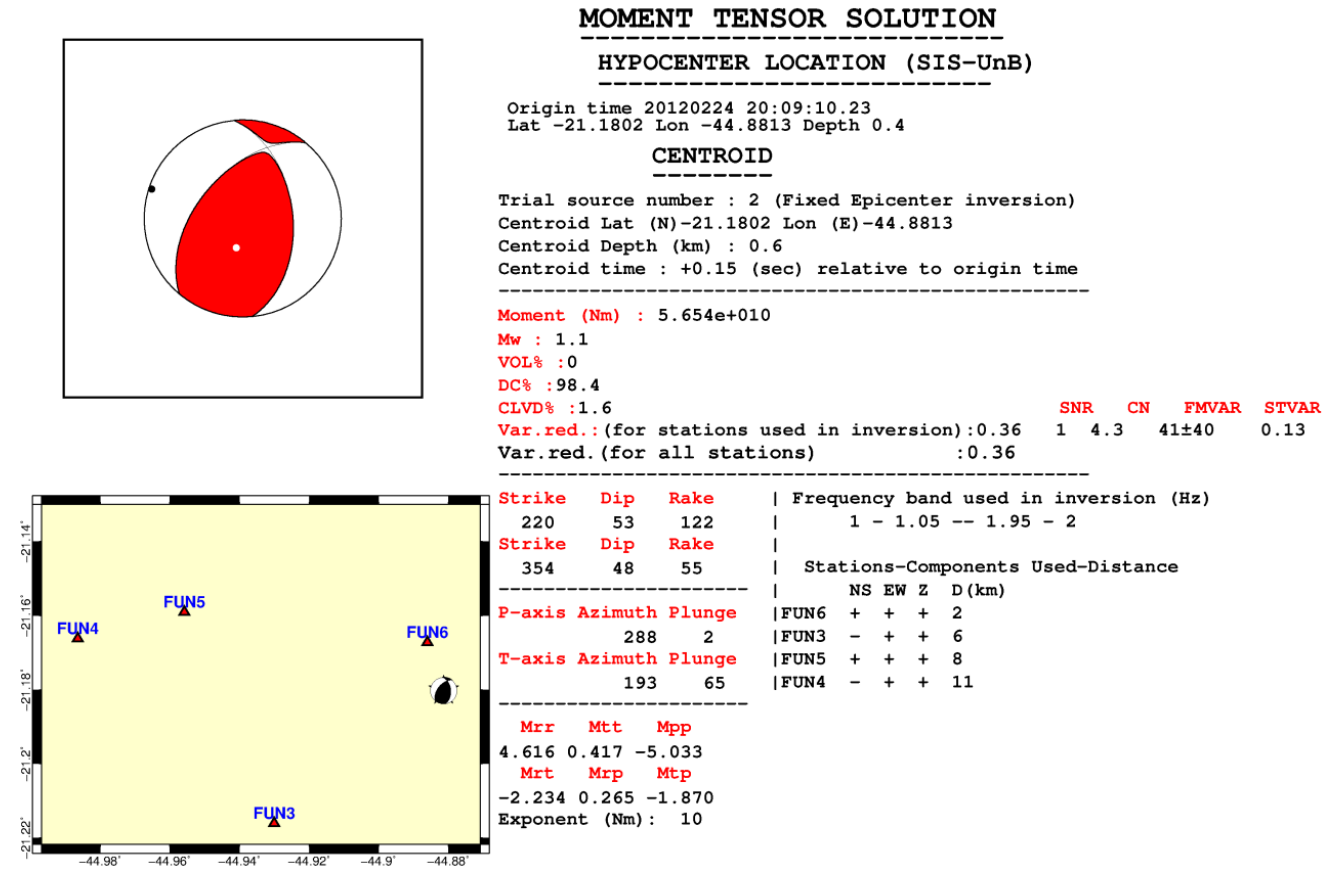

Fig. 6: - Results of Isola waveforms inversion for February 22, 2012 event at 20:09:10.23, recorded in four stations (FUN3, FUN4, FUN5 e FUN6) of Funil seismic network.

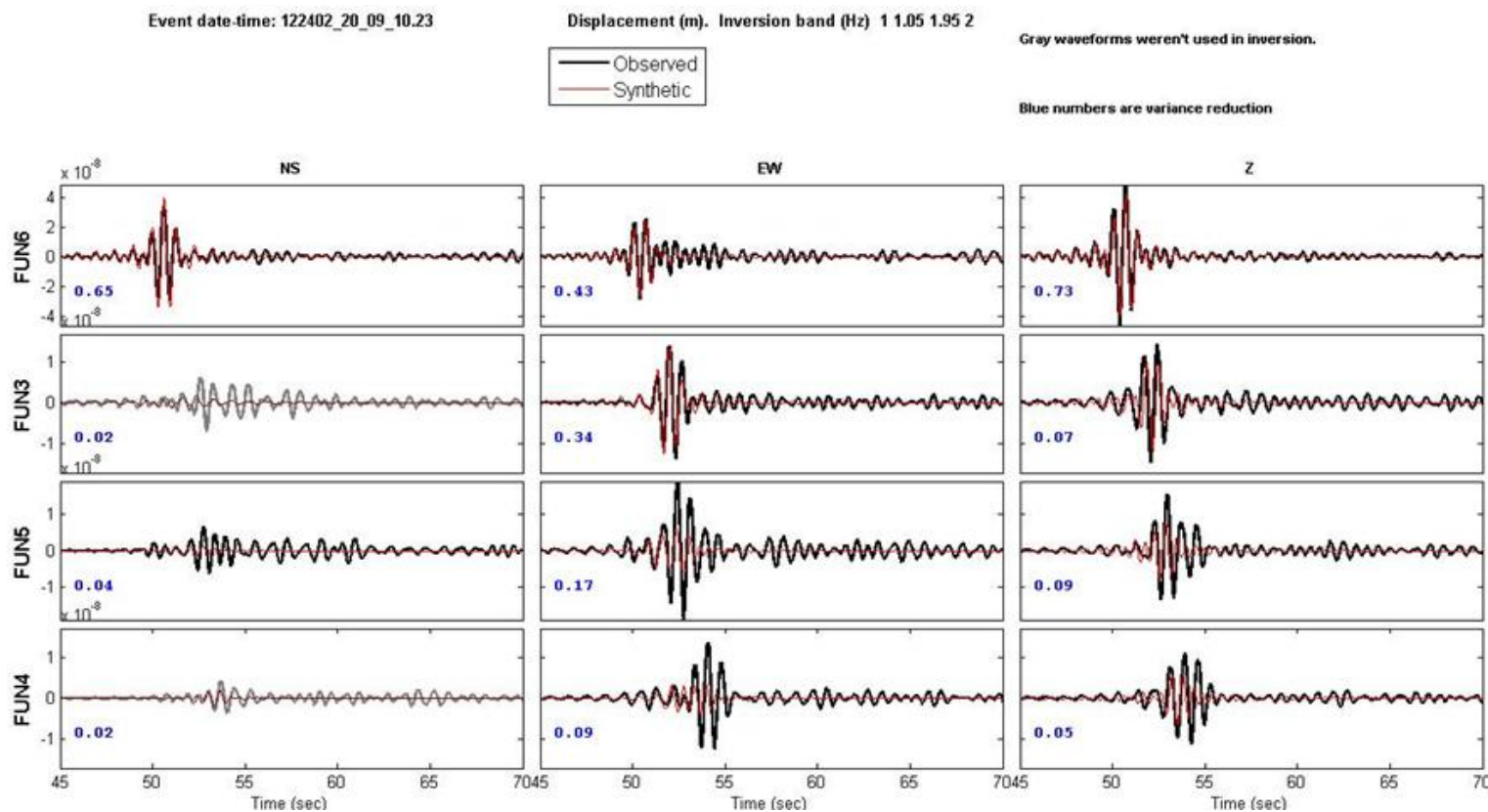

Fig. 7: - Synthetics (red traces) and observed (black traces) seismograms in four stations of the Funil seismic network. The traces of the NS components in the FUN3 and FUN4 stations were not used in the waveforms inversion due to the low Signal to Noise Ratio (SNR).

Table 3: - Focal mechanism parameters for both methods: Composite Focal Mechanism and Waveform Inversion.

\begin{tabular}{cccccc}
\hline Method & Strike & Dip & Rake & P (Strike/Plunge) & T (Strike/Plunge) \\
\hline Composite mechanism & $150 / 359$ & $47 / 47$ & $69 / 111$ & $255 / 3$ & $345 / 75$ \\
Waveform inversion & $221 / 354$ & $53 / 48$ & $123 / 55$ & $288 / 2$ & $193 / 64$ \\
\hline
\end{tabular}




\section{Discussion and conclusions}

Despite of the existence of three potential sources of triggered seismicity very close to the Funil seismic zone, we cannot say which one is responsible for this seismicity. All of these factors can trigger seismicity, together or separated. However, we cannot say which one or ones are contributing to the observed tectonic earthquakes in the area. Moreover, events of these magnitudes can happen anywhere, even in areas where no seismicity had been observed, as it is the case in the area of Funil reservoir seismic zone.

The accuracy of the location of the four major events (represented by the four stars in Fig.1) with data from a single station (FUN1) was studied by evaluating the location of the event from April 22 of 2012, at 20:09:10.23, using data from four stations (FUN1, FUN3, FUN4 and FUN5) and data from a single station (FUN1). In the first case it was used the arrival times of $\mathrm{P}$ and $\mathrm{S}$ phases in the four stations and, in the second, the arrival times of $P$ and $S$ phases, as well as the azimuth as a phase, and fixing the depth. It was observed that these locations differ only of about $1 \mathrm{~km}$. For event located with four stations the hypocenter was the following: origin time $=15: 15: 54.4$; Lat. $=21.191 \mathrm{~S}$; Long. $=44.918 \mathrm{~S}$ and depth $=0.6 \mathrm{~km}$. When located with just FUN1 station (giving zero weight for the $P$ and $S$ phases for all other stations), we have: origin time = 15:15:54.4; Lat. 21.191S; Long. $=44.927 \mathrm{~W}$ and depth $=$ $1 \mathrm{~km}$ (fixed). So, the event is located with a difference of only 1 kilometer in the longitude, as the epicentral distance does not change, because the S-P times difference are the same for both cases.

The Figure 8 shows the composite focal mechanism obtained by the methods of polarities (results in Fig. 4) and the focal mechanism obtained by method of waveform inversion (results in Fig.5). As summarized in Table 3, the two faults obtained by both techniques have more or less the same nature, i.e., both have components of inverse faulting. However, faults parameters differ from each case. For example, comparing the parameters strike, dip and rake obtained by the method of polarity/waveforms inversion method we got for the first plane: strike of $150 / 221$, dip $47 / 53$, rake 69/123 and $P$ and T strike and plunge 255/288 and $345 / 193$, respectively. For the second plane: $359 / 354$, 47/48, 111/55, and for $P$ and $T$ strike and plunge $3 / 2$ and 75/64. We believe that these results are reasonable for a preliminary study, using a single event.

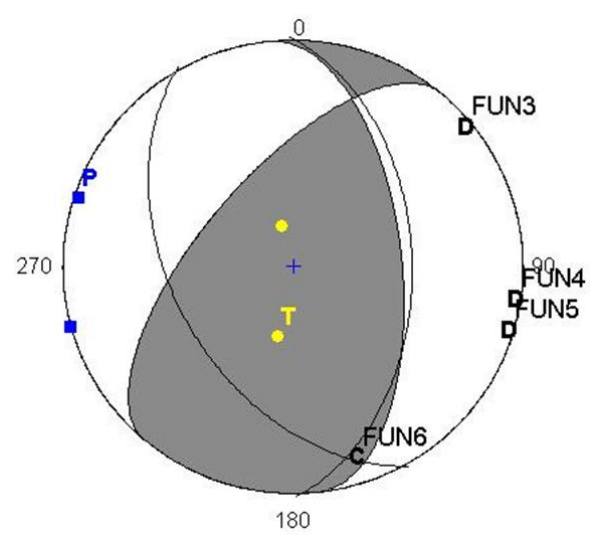

Fig.8: - Focal mechanism of both cases (Fig. 4 plus Fig $5)$. The resume of the results are in Table 3.

Despite the differences between both results, we conclude that the method implemented in the package ISOLA proved to be efficient in getting source parameters by the waveforms inversion of band-passfiltered signals. However, in our case further study is needed, which will be done in near future. Like simultaneous inversion in order to get a better velocity model and, consequently better hypocentral locations, that should interfere in the results of focal mechanism solutions, and of course, in the values of the seismic parameters.

\section{Acknowledgements}

The authors thank very much the Consortium FUNIL Board, in the person of its general president, Eng. Sandro Deives dos Santos and Eng. Paulo Roberto Machado de Carvalho general consortium FUNIL manager, for their cooperation in the data acquisition and for permission to publish this work. The socioenvironmental analysts, Walisson Souza Soares and Jefferson Francisco Soares by the station operations and data collect. The technicians of the Seismological Observatory of the University of Brasilia Francimilton Salustiano da Silva and Daniel Linhares, for their assistance in obtaining data and Professor Marcelo Assumpção for a very profitable discussion.on the focal mechanism results.

\section{References}

Barros, L.V., Albuquerque, D.F., Ferreira, V.M., Von Huelsen, M.G., Mourão, V.F., Fontenele, D.P., Silva, F.S. Soares, J.F and Soares, W.S. 2013. Seismicity of ljaci, south of Minas Gerais state, near the Funil UHE reservoir and mineral extraction areas. XIII International Congress of the Brazilian Geophysical Society. Rio de Janeiro, August 2013.

Berrocal, J., Assumpção, M., Antezana, R., Dias Neto, C., Ortega, R., França, H., Veloso, J.A., 1984. Sismicidade do Brasil. Published by IAG/USP and Comissão Nacional de Energia Nuclear, Brazil, 320p.

Bouchon, M. (1981). A simple method to calculate Green's functions for elastic layered media”, Bull. Seis. Soc. Am., 71, 959-971. 
Dehler, Nolan Maia, and Rômulo Machado. "Analise geométrica e cinemática das rochas metassedimentares da região de ljaci, sul de Minas Gerais." Brazilian Journal of Geology 28.4 (1998): 413-41

Havskov, J. \& Ottemöller, L. (Eds.). SEISAN: The Earthquake Analysis Software, Version 8.1. Inst. of Solid Earth Physics, University of Bergen, Norway, 2008. 227 p.

Kikuchi, M., \& Kanamori., (1991). "Inversion of complex body waves III", Bull. Seis. Soc. Am. 81, 6, 23352350.

Kissling, E., 1995. Program and VELEST user's guide Short introduction. Institute of Geophysics, ETH Zuerich \& Swiss Seismological Service, ETHHoenggerberg. $26 p$.
Lienert, B. R. Hypocenter 3.2: A computer Program for Locating Earthquakes Locally, regionally and globally. Hawaii Institute of Geop. \& Planetology, Corea, 1994.

Snoke, J.A., Munsey, J. W., Teague, A.G., Bollinger, G.A., 1984. A program for focal mechanism determination by combined use of polarity and SV$P$ amplitude data. Earthquake Notes, 55(3), 15.

Sokos, E. N. \& J. ZAHRADNÍK, J., (2008). ISOLA a Fortran code and a Matlab GUI to perform multiple- point source inversion of seismic data, Comput. Geosci. 34, 967-977.

Wessel, P., and Smith, W. H. F., 1995. "New version of the Generic Mapping Tools", released, EOS 76, 329.

Zahradnik, J., and Plesinger, A., 2005. Long-period pulses in broadband records of near earthquakes. Bull. Seism. Soc. Am., 95, 1928-1939.

Zahradnik, J., and S. Custódio (2012). Moment tensor resolvability: Application to southwest Iberia. Bull. Seism. Soc. Am., 102, 1235-1254, doi: 10.1785/0120110216. 